\title{
29. RELATIONSHIP BETWEEN SEDIMENTARY FACIES AND INTERSTITIAL WATER CHEMISTRY OF SLOPE, TRENCH, AND COCOS PLATE SITES FROM THE MIDDLE AMERICA TRENCH TRANSECT, ACTIVE MARGIN OFF GUATEMALA, DEEP SEA DRILLING PROJECT LEG $67^{1}$
}

\author{
William E. Harrison, Oklahoma Geological Survey, University of Oklahoma, Norman, Oklahoma \\ Reinhard Hesse, Department of Geological Sciences, McGill University, Montreal H3A 2A7, Quebec, Canada \\ and \\ Joris M. Gieskes, Scripps Institution of Oceanography, La Jolla, California
}

\begin{abstract}
Interstitial water chemistry has proved to be a sensitive indicator for early diagenetic reactions, particularly those related to organic matter oxidation. Downhole chemical variations in the pore waters from Deep Sea Drilling Project Holes 496 and 497 on the Middle America Trench slope off Guatemala are anomalous because both salinity and chlorinity show strong decreases to half the values of seawater, and $\delta^{18} \mathrm{O}$ values become positive (maximum of about $+2.5 \%$ at the bottom of the holes). These observations are explained in terms of dilution of pore waters after retrieval as a result of decomposition of the gas hydrates before removal of pore waters by shipboard squeezing techniques. In all holes, except Hole 495 (drilled in pelagic sediments), decomposition of organic matter leads to rapid sulfate depletion and subsequent methane generation. Associated with methane generation are large increases in alkalinity and dissolved ammonia. The latter component causes ion exchange reactions with clay minerals, which results in maxima in magnesium and perhaps potassium. At greater depths, as yet unidentified reactions cause the removal of magnesium. Especially in the deeper Trench Sites 499 and 500, rapid variations in calcium, magnesium, and alkalinity occur in turbidite sequences.
\end{abstract}

\section{INTRODUCTION}

One of the major activities of Deep Sea Drilling Project Leg 67 (International Phase of Ocean Drilling) was the drilling into and the recovery of gas hydrates. This was not an original objective of Leg 67 and, indeed, seriously interfered with the original drilling program, because large quantities of gas released by the dissociation of hydrates and the risks involved in coming close to the base of the hydrate zone caused premature termination of drilling at slope Sites 496 to 498 . The danger of hitting a gas reservoir under the hydrate zone thus prevented penetration of deeper parts of the imbricate structures on the Middle America Trench slope seen on seismic profiles (Fig. 1). A normal stratigraphic succession from Quaternary to Upper Cretaceous strata, which was discovered at Site 494 at the base of slope, however, precludes tectonic accretion of trench-fill and pelagic sediments into the Trench wall at this site.

The first-time recovery of gas hydrates from a deep marine sedimentary section achieved on Leg 67 became a significant discovery in its own right, which has important implications for further hydrate research. In this paper some of the implications for early diagenetic reactions are investigated. The hydrate-bearing zone in Holes 496 to 498 shows interesting anomalies in the chemistry of the pore fluids that are here reported and compared to chemical trends in hydrate-free slope, Trench, and Cocos Plate sediments. As has been noted previously (e.g., Gieskes, 1975; Gieskes and Lawrence, \footnotetext{
'Aubouin, J., von Huene, R., et al., Init. Repts. DSDP, 67: Washington (U.S. Govt.
Printing Office).
}

1976), interstitial water studies are most useful in locating horizons and types of reactions during early diagenesis. Anomalies in pore-fluid compositions, particularly downward decreases in salinities and chlorinities, which have been noted during previous DSDP legs, may be explained in the light of hydrate occurrence.

\section{METHODS}

Methods used in this study are based on the routine shipboard squeezing methods described by Manheim and Sayles (1974). Unfortunately the in situ pore-water sampler (Barnes et al., 1979; Moore and Gieskes, 1980) was not operational during this DSDP leg; it would have helped in resolving some of the anomalies discovered in the hydrate-bearing holes.

Chemical analyses were carried out using methods described by Gieskes (1974) and Gieskes and Lawrence (1976). Oxygen isotope measurements were made by the $\mathrm{CO}_{2}$ equilibration method of Epstein and Mayeda (1953).

\section{OBSERVATIONS}

In the following pages results of interstitial water analyses are grouped according to the tectonic environment of the sites: (1) Trench slope with gas hydrates (Sites 496 to 498); (2) lower Trench slope without hydrates (Site 494); (3) pelagic sediments in the Cocos Plate (Site 495); and (4) deep-sea Trench (Sites 499, 500) (see also Fig. 1).

\section{Sites 496 to 498: Trench Slope with Gas Hydrates}

\section{Sedimentary Facies, Geochemistry, and Mineralogy}

Sediments at hydrate-bearing Sites 496,497 , and 498 (water depths of 2064, 2358, and $5497 \mathrm{~m}$, respectively) consist of Quaternary olive gray to very dark gray diato- 


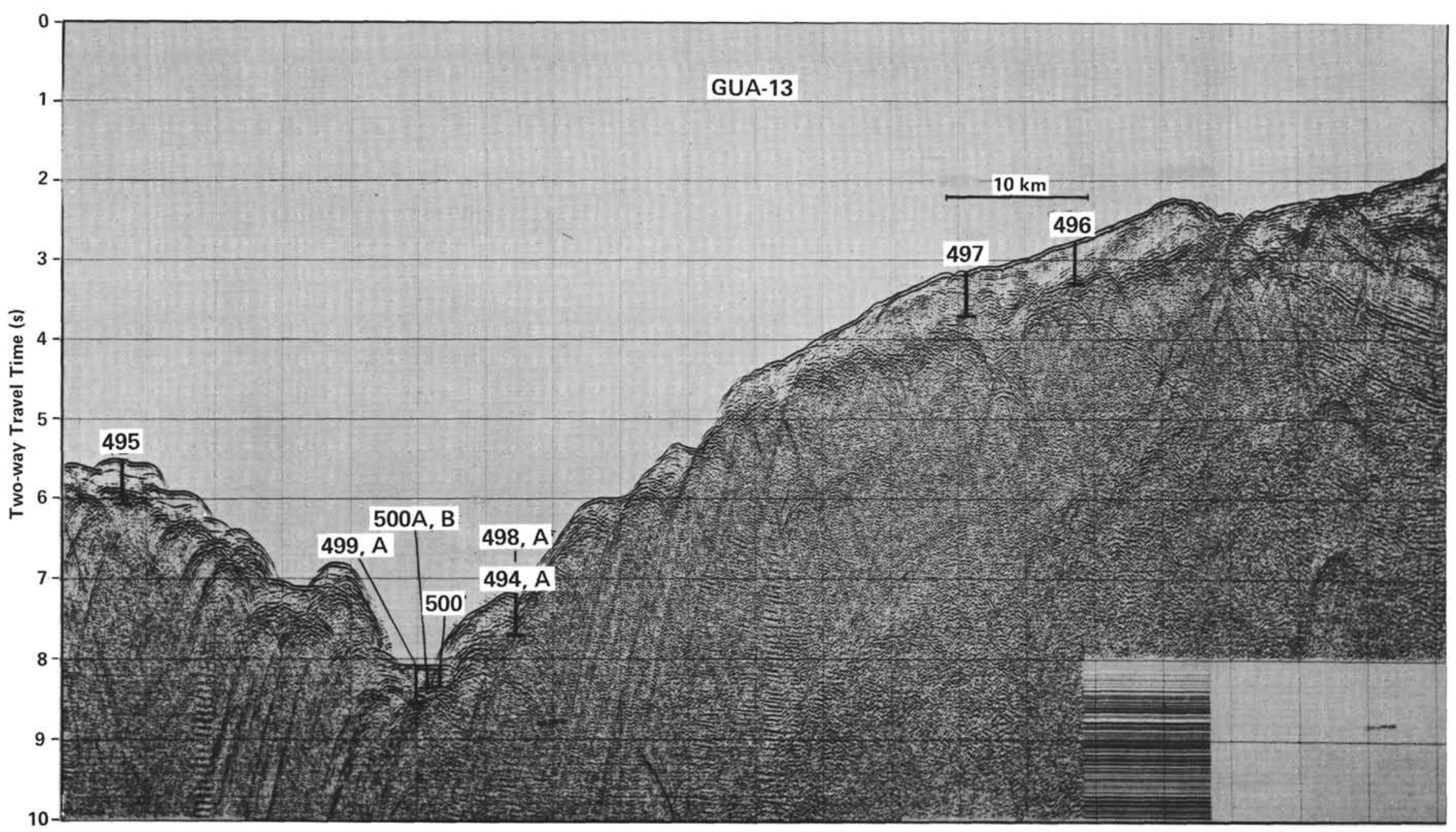

Figure 1. Seismic line GUA-13 (modified from Ibrahim et al., 1979). (Locations of Sites 494 through 500 are indicated. Low reflectivity of the mid-slope section in the vicinity of Sites 496 and 497 indicates the presence of gas hydrates.) 
maceous and nannofossil muds with interbedded ash layers underlain by Pliocene and, in Holes 496 and 498A, Miocene, sandy, dark olive gray mud and mudstone with occasional intercalations of pebbly muds (Holes 496, 497), micritic limestone (Holes 497 and 498A) and volcanic ashes. Sedimentation rates are high in the Quaternary $(130-205 \mathrm{~m} / \mathrm{m} . \mathrm{y}$.) but moderate to low in the older sediments. These sediments were very gas-rich and gave off a strong $\mathrm{H}_{2} \mathrm{~S}$ smell, particularly in the Quaternary part of the sequence, where organic carbon contents are typically 2.0 to $3.5 \%$. In the underlying Pliocene and Miocene sediments, organic carbon reaches about half the Quaternary levels (Fig. 2). It is derived predominantly from terrestrial organic matter as seen on $\mathrm{H} / \mathrm{C}$ versus $\mathrm{O} / \mathrm{C}$ diagrams (see the site reports, this volume), whereas marine organic matter is of secondary importance as an organic-carbon source. Recovered cores showed strong degassing effects. Degassing of the sediments was strongest in those cores near the bottom of Holes 497 and 498A from which the hydrates were recovered. Although hydrates were noticed only in cores from Holes 497 and 498A, they are most likely also present at Site 496, where similarly strong degassing occurred in cores from the deeper part of the hole. The gas hydrates were always associated with relatively coarsegrained sediments (volcanic ashes), whereas the muds and mudstones did not contain any visible hydrates when inspected on board.

In the Hole 496 clay fraction $(<2 \mu \mathrm{m})$ smectite is the dominant clay mineral, followed by kaolinite, illite, and chlorite (Heinemann and Füchtbauer, this volume). The Hole 496 silt fraction $(20-63 \mu \mathrm{m})$ contains generally more than $50 \%$ volcanic glass, the remainder being feldspar, opaline silica, and lesser amounts of zeolites. Quartz forms a minor component of these samples (Heinemann and Füchtbauer, this volume).

\section{Interstitial Water Chemistry (Fig. 3)}

Pore fluids were analyzed from Holes 496 and 497 (Table 1). At Site 498 only three interstitial water samples were obtained, because most of Hole 498 was washed instead of cored and recovery from Hole 498A was generally poor. The analyses for this site are included in Table 2 but not included in the interpretations.

The chemistry of the interstitial waters of Holes 496 and 497 (Fig. 3) shows systematic downhole variations with very pronounced maxima and minima. A marked downward decrease in salinity in the deeper parts of these holes is related to decreases in chlorinity and sodium. In the upper part of Hole 496, however, an increase in salinity is observed, notwithstanding a chlorinity decrease. This salinity increase is associated with a large increase in alkalinity (the largest alkalinity yet observed at any DSDP site). At the same time, maxima in ammonia (below the alkalinity maximum) and in phosphate occur.

Oxygen isotope studies show a downward increase from values near zero at the top of Holes 496 and 497 to $+2.5 \%$ at the bottom. This trend is opposite the usually observed downhole decrease in $\delta^{18} \mathrm{O}$ (Lawrence and Gies-

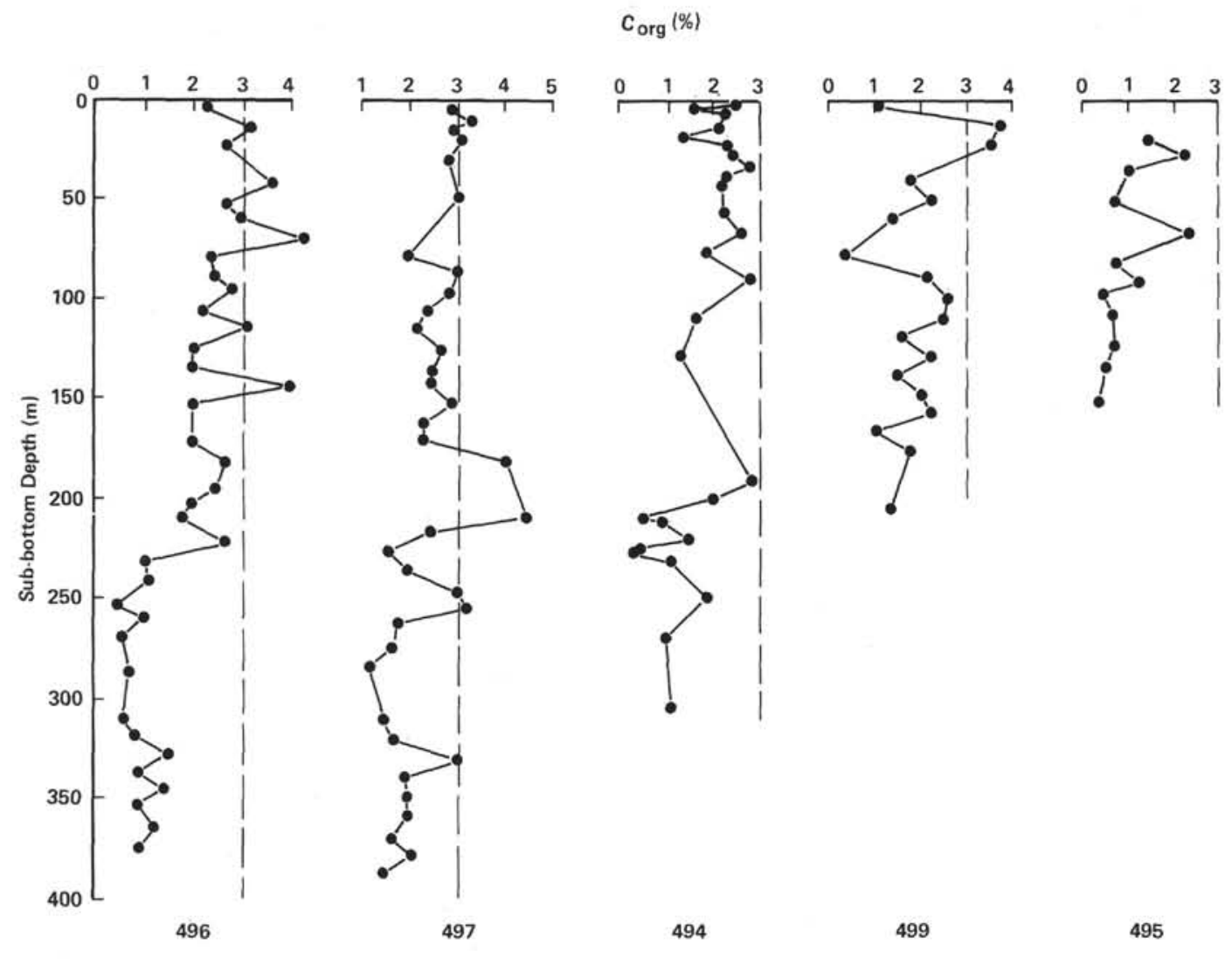

Figure 2. Organic carbon contents, Sites 494 to 497 and 499. 
$\begin{array}{ccccccc}p \mathrm{H} & \mathrm{Sal} & \mathrm{Cl} & \mathrm{Na} & \mathrm{K} & \mathrm{Sr} & \mathrm{Ca} \\ & (\%) & (\%) & & & & \end{array}$ \begin{tabular}{l}
$78162024283236 \quad 1418400 \quad 10 \quad 0.05$ \\
\hline
\end{tabular}

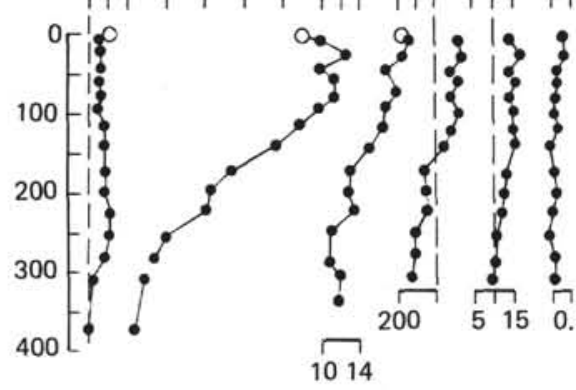

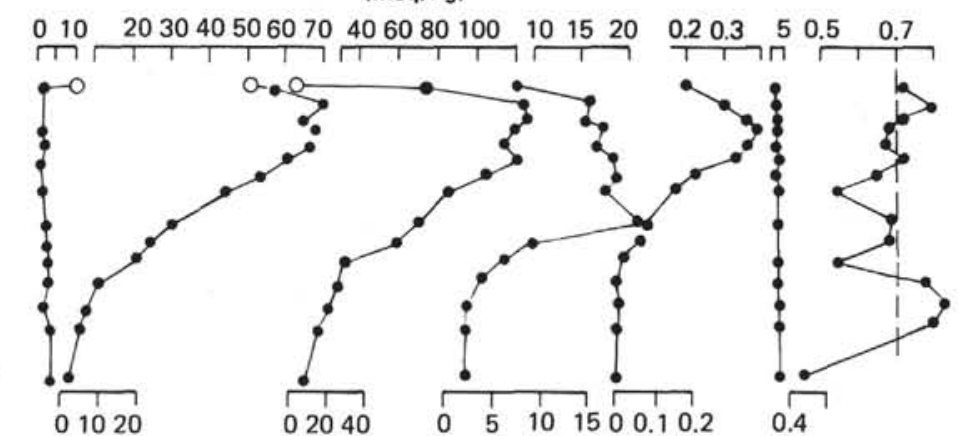

$\mathrm{Mg}$

Alk $(\mathrm{meq} / \mathrm{kg})$

$\mathrm{NH}_{3}$

$\begin{array}{lll}\mathrm{PO}_{4} & \mathrm{SO}_{4} & \mathrm{SiO}_{2}\end{array}$

$203040506070406080100 \quad 1015 \quad 20 \quad 0.20 .3 \quad 50.5 \quad 0.7$

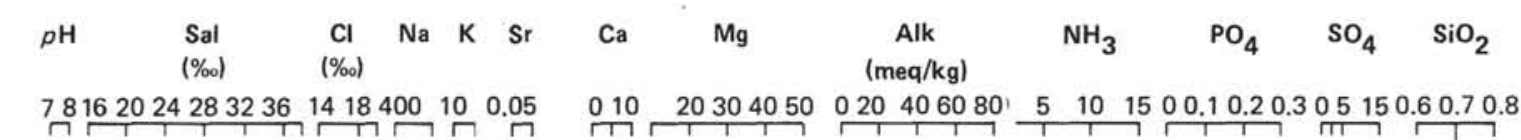
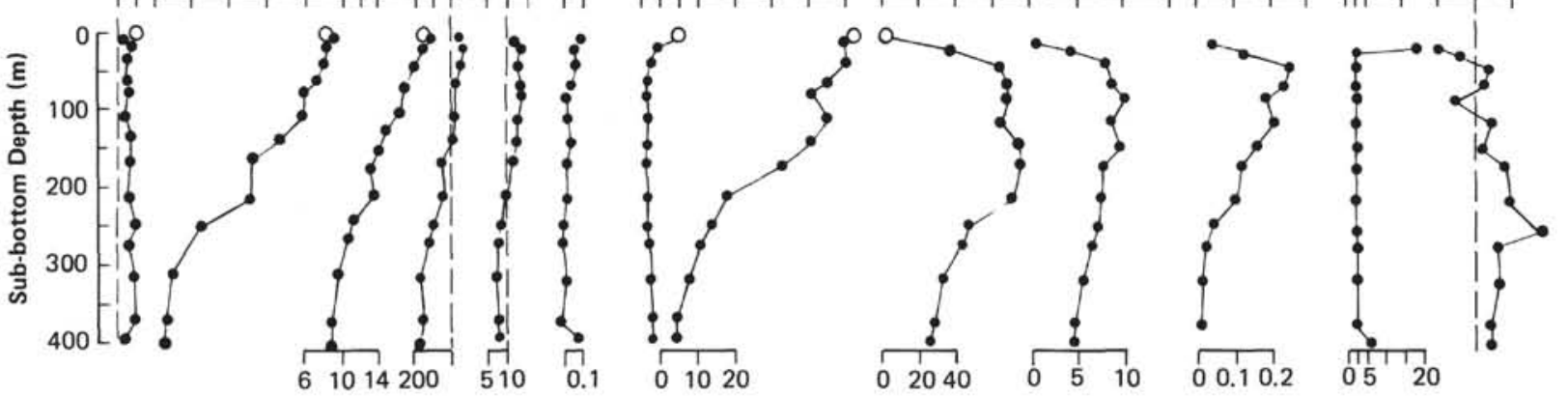

$\delta^{18} \mathrm{O}(\%)$

(SMOW) $0.0 \quad 0.3$

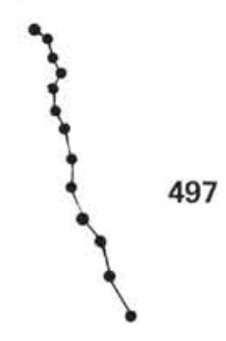

$\mathrm{pH}$

Sal

$\mathrm{Cl}$
$(\% \circ)$

Sr Ca Mg $\begin{gathered}\text { Alk } \\ \text { (meq } / \mathrm{kg})\end{gathered}$

$\mathrm{NH}_{3} \quad \mathrm{PO}_{4}$

$\mathrm{SO}_{4} \quad \mathrm{SiO}_{2} \quad \delta^{18} \mathrm{O}(\%)$ $781620242832361418400 \quad 10150.050 .2101520304050 \quad 02040$

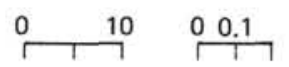

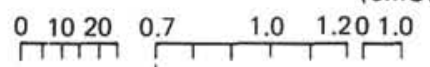
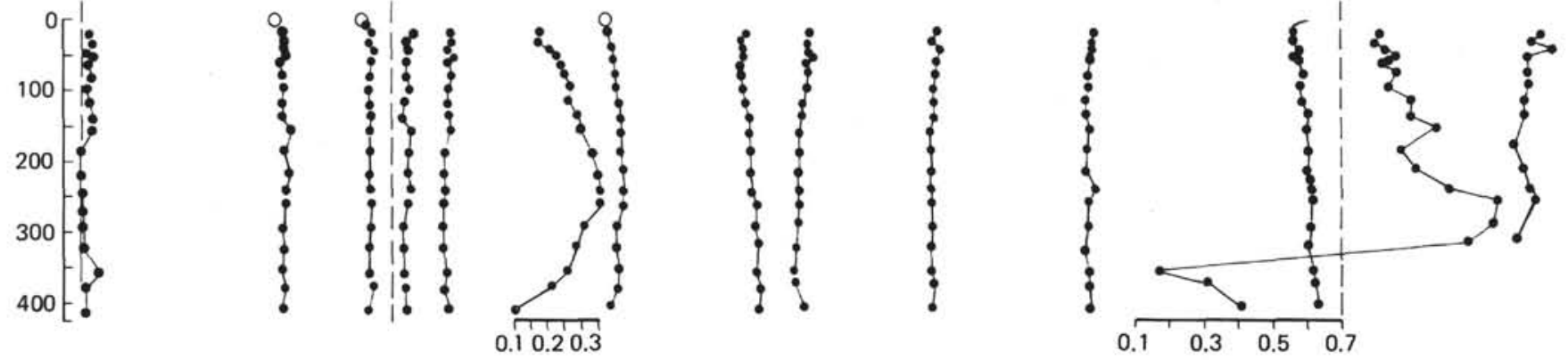

495

Figure 3. Interstitial water chemistry, Sites 496, 497 (mid-slope sites containing gas hydrates), and Site 495 (pelagic sediments, Cocos Plate). (All concentrations are in $\mathrm{m} M$, except where otherwise indicated; $O=$ bottom water.) 
Table 1. Interstitial water data, Leg 67.

\begin{tabular}{|c|c|c|c|c|c|c|c|c|c|c|c|c|c|c|c|}
\hline $\begin{array}{c}\text { Sample } \\
\text { (interval in } \mathrm{cm} \text { ) }\end{array}$ & $\begin{array}{l}\text { Sub-bottom } \\
\text { Depth } \\
\text { (m) }\end{array}$ & $p \mathrm{H}$ & $\begin{array}{l}\text { Sal } \\
(\% 0)\end{array}$ & $\begin{array}{c}\mathrm{Cl} \\
(\%)\end{array}$ & $\underset{(\mathrm{m} M)}{\mathrm{Na}}$ & $\underset{(\mathrm{m} M)}{\mathrm{K}}$ & $\begin{array}{c}\mathrm{Mg} \\
(\mathrm{mM})\end{array}$ & $\underset{(\mathrm{m} M)}{\mathrm{Ca}}$ & $\underset{(\mathrm{m} M)}{\mathrm{Sr}}$ & $\begin{array}{c}\text { Alk } \\
(\mathrm{meq} / \mathrm{kg})\end{array}$ & $\begin{array}{c}\mathrm{SO}_{4} \\
(\mathrm{mM})\end{array}$ & $\begin{array}{l}\mathrm{NH}_{4} \\
(\mathrm{~m} M)\end{array}$ & $\begin{array}{l}\mathrm{PO}_{4} \\
(\mathrm{mM})\end{array}$ & $\begin{array}{l}\mathrm{SiO}_{2} \\
(\mathrm{mM})\end{array}$ & $\begin{array}{c}\delta^{18} \mathrm{O} \\
(\% \circ) \text { (SMOW) }\end{array}$ \\
\hline \multicolumn{16}{|l|}{ Hole 495} \\
\hline $3-4,144-150$ & 25.0 & 7.37 & 35.2 & 19.5 & 509 & 13 & 45.9 & 11.0 & 0.18 & 9.60 & 21.0 & 0.830 & 0.0225 & 0.809 & +0.32 \\
\hline $4-4,140-150$ & 34.0 & 7.53 & 35.2 & 19.3 & 496 & 14 & 44.9 & 11.6 & 0.18 & 9.54 & 21.0 & 0.581 & 0.0209 & 0.804 & +0.14 \\
\hline $5-5,144-150$ & 45.0 & 7.34 & 35.2 & 19.4 & 487 & 13 & 45.1 & 11.8 & 0.20 & 9.7 & 21.5 & 0.896 & 0.0191 & 0.819 & +0.73 \\
\hline $6-3,144-150$ & 52.0 & 7.43 & 35.2 & 19.3 & 487 & 14 & 45.5 & 12.6 & 0.22 & 10.3 & 20.6 & 0.867 & 0.0170 & 0.850 & +0.21 \\
\hline $7-3,144-150$ & 61.5 & 7.31 & 34.9 & 19.5 & 487 & 13 & 44.9 & 12.6 & 0.23 & 8.91 & 22.5 & 0.835 & 0.0092 & 0.832 & -0.04 \\
\hline $9-5,144-150$ & 83.5 & 7.56 & 34.9 & 19.3 & 487 & 14 & 45.2 & 13.0 & 0.24 & 8.07 & 23.2 & 0.685 & 0.0064 & 0.859 & +0.01 \\
\hline $11-2,144-150$ & 98.0 & 7.37 & 35.2 & 19.3 & 491 & 13 & 45.5 & 13.7 & 0.26 & 7.36 & 22.7 & 0.591 & 0.0081 & 0.835 & -0.02 \\
\hline $13-4,144-150$ & 120.0 & 7.45 & 35.2 & 19.3 & 474 & 13 & 46.4 & 13.7 & 0.26 & 5.74 & 23.4 & 0.463 & 0.0026 & 0.900 & -0.09 \\
\hline $15-5,144-150$ & 140.5 & 7.56 & 35.2 & 19.3 & 461 & 13 & 46.8 & 14.1 & 0.28 & 5.73 & 24.9 & 0.426 & $<0.0025$ & 0.899 & - \\
\hline $17-5,144-150$ & 159.5 & 7.52 & 36.0 & 19.3 & 513 & 13 & 47.2 & 14.2 & 0.30 & 4.64 & 24.2 & 0.010 & 0.0093 & 0.967 & - \\
\hline $20-5,144-150$ & 188.0 & 7.03 & 35.5 & 19.4 & 504 & 11 & 47.2 & 14.9 & 0.32 & 4.14 & 25.1 & 0.028 & 0.0034 & 0.871 & - \\
\hline $23-6,144-150$ & 218.0 & 6.99 & 36.0 & 19.4 & 496 & 11 & 47.4 & 14.9 & 0.34 & 3.80 & 24.7 & 0.004 & 0.0039 & 0.909 & - \\
\hline $26-5,144-150$ & 245.0 & 6.96 & 35.5 & 19.3 & 513 & 11 & 48.8 & 15.7 & 0.35 & 3.88 & 25.1 & 0.201 & 0.0219 & 1.090 & -0.01 \\
\hline $29-6,144-150$ & 273.5 & 7.05 & 35.5 & 19.5 & 491 & 10 & 49.1 & 15.7 & 0.35 & 3.59 & 25.3 & 0.176 & 0.0071 & 1.150 & +0.13 \\
\hline $32-1,144-150$ & 296.0 & 7.11 & 35.2 & 19.5 & 474 & 11 & 49.4 & 14.3 & 0.30 & 2.26 & 25.1 & 0.252 & 0.0029 & 1.140 & - \\
\hline $35-2,140-150$ & 326.0 & 7.22 & 35.5 & 19.3 & 478 & 11 & 50.4 & 14.7 & 0.29 & 1.80 & 24.7 & 0.107 & $<0.0025$ & 1.060 & -0.32 \\
\hline $39-2,140-150$ & 364.0 & 8.07 & 35.2 & 19.4 & 474 & 12 & 48.1 & 14.3 & 0.25 & 0.42 & 25.9 & 0.036 & 0.0040 & 0.159 & - \\
\hline $41-2,140-150$ & 383.0 & 7.27 & 35.5 & 19.6 & 478 & 11 & 49.9 & 14.3 & 0.21 & 0.70 & 26.2 & 0.110 & 0.0029 & 0.303 & - \\
\hline $45-5,140-150$ & 422.5 & 7.30 & 35.2 & 19.2 & 478 & 12 & 49.4 & 11.8 & 0.10 & 2.08 & 26.8 & 0.160 & 0.0054 & 0.402 & - \\
\hline \multicolumn{16}{|l|}{ Hole 496} \\
\hline $1-4,144-150$ & 6.0 & 7.58 & 36.0 & 19.1 & 513 & 14 & 57.6 & 1.9 & 0.08 & 68.5 & $<3.0$ & 7.90 & 0.200 & 0.717 & +0.19 \\
\hline $3-4,144-150$ & 23.0 & 7.60 & 38.5 & 18.6 & 522 & 16 & 70.6 & 1.4 & 0.08 & 120.8 & $<3.0$ & 15.80 & 0.303 & 0.793 & +0.23 \\
\hline $5-6,144-150$ & 45.0 & 7.58 & 35.8 & 16.6 & 474 & 14 & 64.6 & 1.2 & 0.06 & 120.4 & 3.1 & 15.30 & 0.357 & 0.710 & +0.77 \\
\hline $7-1,144-150$ & 56.5 & 7.58 & 37.1 & 17.6 & 504 & 15 & 68.2 & 1.4 & 0.06 & 115.7 & $<3.0$ & 16.90 & 0.383 & 0.677 & +0.43 \\
\hline $9-3,144-150$ & 78.5 & 7.53 & 37.1 & 17.9 & 478 & 14 & 66.6 & 2.0 & 0.06 & 107.8 & $<3.0$ & 16.60 & 0.364 & 0.656 & +0.82 \\
\hline $11-2,144-150$ & 96.0 & 7.58 & 35.5 & 16.7 & 517 & 15 & 60.3 & 1.5 & 0.06 & 112.4 & 3.3 & 17.80 & 0.331 & 0.716 & +0.70 \\
\hline $13-2,144-150$ & 115.0 & 7.76 & 33.8 & 16.4 & 448 & 15 & 52.7 & 1.3 & 0.06 & 97.6 & $<3.0$ & 18.20 & 0.214 & 0.637 & +0.67 \\
\hline $15-4,140-150$ & 137.0 & 7.85 & 31.6 & 15.8 & 465 & 15 & 44.3 & 1.6 & 0.05 & 78.2 & $<3.0$ & 17.20 & 0.166 & 0.529 & +0.92 \\
\hline $19-4,140-150$ & 175.5 & 7.79 & 26.4 & 13.1 & 348 & 13 & 29.1 & 1.7 & 0.06 & 63.0 & $<3.0$ & 21.40 & 0.096 & 0.688 & +1.12 \\
\hline $21-8,140-150$ & 200.0 & 7.75 & 24.8 & 13.0 & 343 & 12 & 24.4 & 1.8 & 0.06 & 51.5 & $<3.0$ & 9.25 & 0.078 & 0.674 & +1.71 \\
\hline $24-4,144-150$ & 221.7 & 7.96 & 24.2 & 13.3 & 350 & 12 & 20.2 & 2.1 & 0.05 & 25.7 & $<3.0$ & 6.25 & 0.024 & 0.528 & +1.62 \\
\hline $27-6,140-150$ & 254.0 & 7.88 & 19.8 & 11.0 & 295 & 10 & 8.6 & 1.3 & 0.04 & 20.8 & $<3.0$ & 4.01 & 0.014 & 0.763 & +1.77 \\
\hline $30-5,140-150$ & 281.0 & 7.76 & 18.7 & 11.0 & 287 & 10 & 7.5 & 2.5 & 0.05 & 17.1 & $<3.0$ & 2.68 & 0.016 & 0.817 & +2.50 \\
\hline $33-6,140-150$ & 311.0 & 7.90 & 17.6 & 10.3 & 281 & 9 & 5.4 & 2.6 & 0.05 & 15.1 & $<3.0$ & 2.52 & 0.010 & 0.758 & +2.10 \\
\hline $40-8,100-110$ & 380.5 & 8.01 & 16.2 & 9.6 & - & - & 1.9 & 2.2 & - & 6.95 & $<3.0$ & 2.19 & $<0.002$ & 0.430 & +2.59 \\
\hline \multicolumn{16}{|l|}{ Hole 497} \\
\hline $1-3,140-150$ & 4.5 & 7.56 & 34.9 & 19.1 & 443 & 12 & 50.1 & 9.1 & 0.09 & 10.1 & 20.4 & 0.709 & 0.045 & 0.595 & +0.14 \\
\hline $2-6,144-150$ & 16.0 & 7.68 & 34.1 & 18.9 & 456 & 13 & 49.9 & 4.1 & 0.08 & 36.6 & 3.0 & 4.020 & 0.136 & 0.651 & +0.37 \\
\hline $5-2,140-150$ & 38.5 & 7.51 & 34.1 & 17.8 & 448 & 13 & 49.8 & 2.2 & 0.08 & 64.0 & 3.0 & 8.260 & 0.255 & 0.741 & +0.60 \\
\hline $7-5,140-150$ & 62.0 & 7.51 & 33.0 & 17.1 & 431 & 14 & 44.5 & 1.6 & 0.07 & 67.1 & 3.0 & 8.950 & 0.239 & 0.718 & +0.70 \\
\hline $9-3,140-150$ & 78.0 & 7.62 & 31.9 & 16.5 & 423 & 14 & 41.7 & 1.3 & 0.06 & 67.9 & 3.0 & 10.400 & 0.202 & 0.643 & +0.66 \\
\hline $12-3,144-150$ & 106.7 & 7.53 & 31.6 & 16.2 & 423 & 13 & 45.0 & 2.0 & 0.06 & 67.1 & 3.0 & 8.820 & 0.211 & 0.747 & +0.60 \\
\hline $15-5,140-150$ & 138.0 & 7.75 & 29.4 & 14.7 & 413 & 13 & 40.1 & 1.7 & 0.07 & 75.7 & 3.0 & 9.660 & 0.161 & 0.713 & +0.74 \\
\hline $18-5,140-150$ & 166.7 & 7.75 & 26.1 & 12.9 & 352 & 12 & 32.5 & 2.0 & 0.06 & 72.5 & 3.0 & 7.970 & 0.128 & 0.780 & +1.02 \\
\hline $23-2,140-150$ & 209.5 & 7.55 & 26.1 & 13.6 & 361 & 10 & 30.7 & 2.4 & 0.06 & 45.1 & 3.0 & 7.640 & 0.104 & 0.789 & +1.02 \\
\hline $26-2,140-150$ & 238.0 & 7.80 & 21.2 & 11.3 & 311 & 9 & 18.6 & 1.8 & 0.05 & 38.0 & 3.0 & 7.360 & 0.048 & 0.884 & +1.35 \\
\hline $29-4,140-150$ & 272.5 & 7.66 & 19.8 & 10.5 & 283 & 8 & 16.9 & 2.40 & 0.05 & 31.1 & 3.0 & 6.670 & 0.029 & 0.757 & +1.68 \\
\hline $34-2,140-150$ & 314.0 & 7.88 & 16.8 & 9.3 & 233 & 8 & 10.9 & 2.5 & 0.06 & 25.9 & 3.0 & 5.700 & 0.017 & 0.759 & +1.89 \\
\hline $39-7,140-150$ & 369.5 & 7.95 & 16.5 & 9.1 & 251 & 8 & 8.8 & 3.1 & 0.04 & 18.6 & 3.0 & 4.830 & $<0.010$ & 0.739 & +2.52 \\
\hline $42-5,140-150$ & 394.5 & 7.35 & 16.2 & 9.0 & 230 & 8 & 7.2 & 2.8 & 0.10 & 17.1 & 5.9 & 4.460 & 0.000 & 0.737 & - \\
\hline
\end{tabular}

Note: - indicates sample was not analyzed. SMOW $=$ standard mean ocean water.

kes, 1981). In a subsequent section this phenomenon will be discussed in greater detail, particularly in relation to the problem of gas-hydrate formation.

\section{Site 494: Trench Slope without Gas Hydrates}

\section{Sedimentary Facies}

The Site 494 sedimentary section at the base of the Trench slope ( $5529 \mathrm{~m}$ water depth), $3 \mathrm{~km}$ landward from and 580 meters above the Trench floor, consists of five distinct lithologic units that are separated by unconformities or faults: (1) an upper Holocene to Pliocene, dark olive gray, diatomaceous mud and semi-indurated mudstone, 213 meters thick, containing micritic limestone fragments. Benthic foraminifers, ostracode and pelecypod fragments, and plant remains attest to a provenance from areas of much shallower depth (i.e., less than $2000 \mathrm{~m})$. Sedimentation rates are moderate $(55 \mathrm{~m} /$ m.y.). (2) A 27-meter-thick, lower Miocene to upper Oligocene, bluish gray, hemipelagic clay to claystone (from 213-240 m sub-bottom depth), which contains open-ocean nannofossil assemblages and, again, micritic limestone fragments. Sedimentation rates are very low ( $3 \mathrm{~m} / \mathrm{m} . y$.$) . (3) A 54-meter-thick, middle Eocene, dark$ sandy mudstone (from 240-294 m sub-bottom depth) deposited below the foraminiferal calcite compensation level (CCL) - but above the CCL for nannofossils-at moderate to low sedimentation rates $(10 \mathrm{~m} / \mathrm{m}$.y.). (4) 19 meters (295-314 m sub-bottom depth) of middle Eocene to Upper Cretaceous, dark olive gray, nannofossil-rich 
Table 2. Interstitial water data, Leg 67.

\begin{tabular}{|c|c|c|c|c|c|c|c|c|}
\hline $\begin{array}{c}\text { Sample } \\
\text { (interval in } \mathrm{cm} \text { ) }\end{array}$ & $\begin{array}{l}\text { Sub-bottom } \\
\text { Depth } \\
\text { (m) }\end{array}$ & $p \mathrm{H}$ & $\begin{array}{l}\text { Sal } \\
(\% 0)\end{array}$ & $\begin{array}{c}\mathrm{Cl} \\
(\%)\end{array}$ & $\underset{(\mathrm{mM})}{\mathrm{M}}$ & $\underset{(\mathrm{m} M)}{\mathrm{Ca}}$ & $\begin{array}{c}\text { Alk } \\
(\mathrm{meq} / \mathrm{l})\end{array}$ & $\begin{array}{l}\delta^{18} \mathrm{O} \\
\left(\%_{0}\right)\end{array}$ \\
\hline \multicolumn{9}{|l|}{494} \\
\hline $1-5,144-150$ & 7.4 & 7.66 & 37,7 & 19.1 & 55.6 & 3.2 & 83.3 & - \\
\hline $3-5,144-150$ & 23 & 7.57 & 37.4 & 19.0 & 61.9 & 2.9 & 80.4 & - \\
\hline $4-3,144-150$ & 32 & 7.67 & 37.1 & 19.3 & 57.1 & 2.0 & 71.5 & - \\
\hline \multicolumn{9}{|l|}{$494 \mathrm{~A}$} \\
\hline $1-3,144-150$ & 42 & 7.62 & 35,8 & 19.1 & 55.1 & 2.5 & 58.4 & - \\
\hline $8-1,144-150$ & 105 & 7.73 & 35.5 & 19.0 & 55.1 & 2.5 & 58.4 & - \\
\hline $17-1,140-150$ & 191 & 7.54 & 33.3 & 19.1 & 45.4 & 11.6 & 16.1 & - \\
\hline $19-1,140-150$ & 210 & 7.33 & 33.0 & 19.5 & 40.6 & 17.5 & 7.28 & - \\
\hline $22-3,110-120$ & 241 & 7.59 & 34.1 & 19.7 & 28.3 & 42.9 & 2.50 & - \\
\hline \multicolumn{9}{|l|}{498} \\
\hline $1-2,144-150$ & 3.0 & 7.67 & 34.9 & 19.1 & 52.9 & 4.8 & 44.3 & - \\
\hline \multicolumn{9}{|l|}{$498 \mathrm{~A}$} \\
\hline $5-4,140-150$ & 218 & 7.88 & 33.8 & 19.6 & 47.2 & 5.5 & - & - \\
\hline $8-3,140-150$ & 245 & 7.68 & 33.3 & 19.6 & 41.6 & 12.5 & 12.3 & - \\
\hline \multicolumn{9}{|l|}{499} \\
\hline $2-5,144-150$ & 8.5 & 7,49 & 38.5 & 19.3 & 73.5 & 4.1 & 100,9 & +0.097 \\
\hline $3-3,144-150$ & 15 & 7.67 & 38.5 & 19.9 & 70.6 & 4.6 & 89.0 & +0.05 \\
\hline $5-5,0-10$ & 35.6 & 7.07 & 35.2 & 20.2 & 27.1 & 37.4 & 19.0 & +0.35 \\
\hline $6-4,144-150$ & 45 & 7.11 & 34.9 & 19.7 & 12.5 & 54.1 & 10.4 & +0.42 \\
\hline $10-2,144-150$ & 80 & 7.60 & 34.9 & 19.5 & 41.9 & 3.7 & 37.2 & -0.096 \\
\hline $12-2,144-150$ & 99 & 7.51 & 37,4 & 19.6 & 56.9 & 4.5 & 77.5 & +0.39 \\
\hline $14-2,144-150$ & 118 & 7.48 & 38.0 & 19.2 & 59.9 & 5.5 & 88.2 & +0.097 \\
\hline $17-3,140-150$ & 148 & 7.48 & 35.8 & 19.1 & 47.2 & 9.3 & 49.6 & +0.22 \\
\hline $19-4,140-150$ & 168.5 & 7.38 & 34.1 & 19.5 & 35.5 & 15.3 & 25.7 & +0.22 \\
\hline $22-5,140-150$ & 198.5 & 7.30 & 34.9 & 19.7 & 29.7 & 34.3 & 6.24 & - \\
\hline $25 \cdot 3,140-150$ & 224 & 6.90 & 35.5 & 19.5 & 31.6 & 38.5 & 2.00 & 0.00 \\
\hline \multicolumn{9}{|l|}{500} \\
\hline $1-1,144-150$ & 1.5 & 7.67 & 34.9 & 19.2 & 52.5 & 4.6 & 45.7 & -0.38 \\
\hline $2-2,119-125$ & 7.2 & 7.50 & 37.4 & 19.9 & 60.1 & 3.1 & 57.5 & +0.35 \\
\hline $3-3,144-150$ & 18.5 & 7.42 & 36.3 & 19.6 & 54.9 & 2.8 & 49.7 & +0.23 \\
\hline $4-3,140-150$ & 28 & 7.67 & 35.2 & 19.45 & 49.7 & 1.9 & 45.0 & +0.46 \\
\hline $7-7,144-150$ & 62.5 & 7.64 & 34.9 & 19.5 & 41,0 & 1.7 & 41.3 & +0.51 \\
\hline $9-7,144-150$ & 82 & 7.85 & 36.3 & 19.6 & 52.7 & 2.4 & 62.6 & - \\
\hline $13-1,144-150$ & 110.5 & 7.32 & 34.1 & 19.2 & 47.6 & 1.6 & 39.0 & - \\
\hline $15-4,140-150$ & 134 & 7.11 & 33.3 & 19.2 & 41.4 & 3.8 & 16.2 & - \\
\hline $17-4,140-150$ & 153 & 7.33 & 32.2 & 19.1 & 37.2 & 5.5 & 3.35 & - \\
\hline
\end{tabular}

Note: - indicates sample was not analyzed.

mudstone mixed with pebbles of bluish gray chalk and micritic limestone. (5) Globotruncana-bearing, medium gray limestone also occurs in the deepest cores down to the bottom $(366.5 \mathrm{~m})$ of Hole $494 \mathrm{~A}$, where it is associated with pebbles of intermediate to mafic igneous rocks.

Organic carbon content ranges between 1.2 and $2.8 \%$ in the clayey sediments of Unit 1 . Below 200 meters subbottom depth, only a few samples exceed $1 \% \mathrm{C}_{\text {org }}$ (Fig. 2 ). In the clay fraction, smectite is the dominant mineral (in most samples $>60 \%$ ), with illite and kaolinite forming minor components (Heinemann and Füchtbauer, this volume). In a few samples chlorite is also present. The coarse silt fraction $(20-63 \mu \mathrm{m})$ is dominated by plagioclases. Quartz occurs as a subordinate component. Opaline silica is subordinate in samples with high terrigenous supply, but is relatively enriched in some middle Eocene and Upper Cretaceous samples with low terrigenous influx. Admixture of a considerable fraction of brownish, presumably basaltic glass fragments was observed.

\section{Interstitial Water Chemistry (Fig. 4)}

Analyses are presently available for salinity, $\mathrm{Cl}^{-}$, $p \mathrm{H}, \mathrm{Ca}^{2+}, \mathrm{Mg}^{2+}$, and alkalinity only (Table 2) and samples studied from Lithologic Units 1, 2, and 3 (top only).

Again a rapid increase in alkalinity $(>80 \mathrm{meq} / \mathrm{l}$ at 7.4 $\mathrm{m}$ ) is accompanied by a maximum in salinity and mag- nesium, similar to the observations for Hole 496, though less pronounced. Below this depth, salinities decrease to about $33 \%$ as a result of rapid decreases in alkalinity, magnesium, and sulfate (not determined), whereas chlorinity increases slightly downhole. Calcium first decreases to values below $5 \mathrm{mM}$, as in the upper slope holes, but shows a marked increase in the deeper parts of Hole 494A (in the middle Eocene nannofossil-bearing mudstone).

\section{Site 495: Hemipelagic and Pelagic Sediments on the Cocos Plate}

\section{Sedimentary Facies}

Site 495 , located $22 \mathrm{~km}$ oceanward from the Trench axis (in $4150 \mathrm{~m}$ water depth; i.e., $1925 \mathrm{~m}$ above the Trench floor), contains the normal and complete vertical stratigraphic succession of pelagic facies predicted by the pelagic sedimentation model for subsiding oceanic crust on a ridge flank (Hesse et al., 1974). Unit 1, the uppermost of the four lithologic units, is a 171-meter-thick hemipelagic, diatomaceous, greenish gray to olive gray mud, deposited in the Quaternary to late Miocene, which represents the time when the site was within a distance of $900 \mathrm{~km}$ from the Guatemalan margin, according to spreading rate and direction of motion of the Cocos Plate (von Huene et al., 1980). Terrigenous influence from the continent may have been felt to such distance in the late Miocene and Pliocene. Alternatively, if spreading rates of the Cocos Plate were less than at present $(9 \mathrm{~cm} / \mathrm{y}$.), the distance from the continent at the time when hemipelagic sedimentation started would have been less. (2) Unit 2 consists of 7 meters (171-178 m subbottom depth) of middle Miocene, brown abyssal clay corresponding to the time when the site had subsided below the calcite compensation level in the area of decreasing biogenic productivity north of the equator. (3) Unit 3 comprises 228 meters of carbonate ooze (178$406 \mathrm{~m}$ sub-bottom depth) that were deposited in the early and middle Miocene, when the site was closer to the ridge crest and above the calcite compensation level. Increased sedimentation rates $(40 \mathrm{~m} / \mathrm{m} . \mathrm{y}$.) in the middle Miocene indicate passage of the site under the equatorial belt of high productivity. The lower part of this unit was lithified to form chalk. (4) The basal unit consists of 22.5 meters of pale brown, manganiferous chalk (406-428.5 m sub-bottom depth) deposited on basalt in the vicinity of the ridge crest where hydrothermal activity is most intense.

Mineralogic composition (see Heinemann and Füchtbauer, this volume) of the coarse silt fraction (20-63 $\mu \mathrm{m}$ ) of the hemipelagic muds (Lithologic Unit 1) is dominated by volcanic glass, which also is the predominant constituent in the $>2.43 \mathrm{~g} / \mathrm{cm}^{3}$ density fraction of the brown abyssal clay (Unit 2) and the upper part of the carbonate ooze. In the light fraction (density $<2.43$ $\mathrm{g} / \mathrm{cm}^{3}$ ), however, biogenic opaline silica becomes the predominant component of the noncarbonate material in Units 2 and 3. Feldspars and, at the bottom of the hole, zeolites form subordinate to abundant (i.e., feldspars in the upper parts of Unit 1) constituents. Clay 

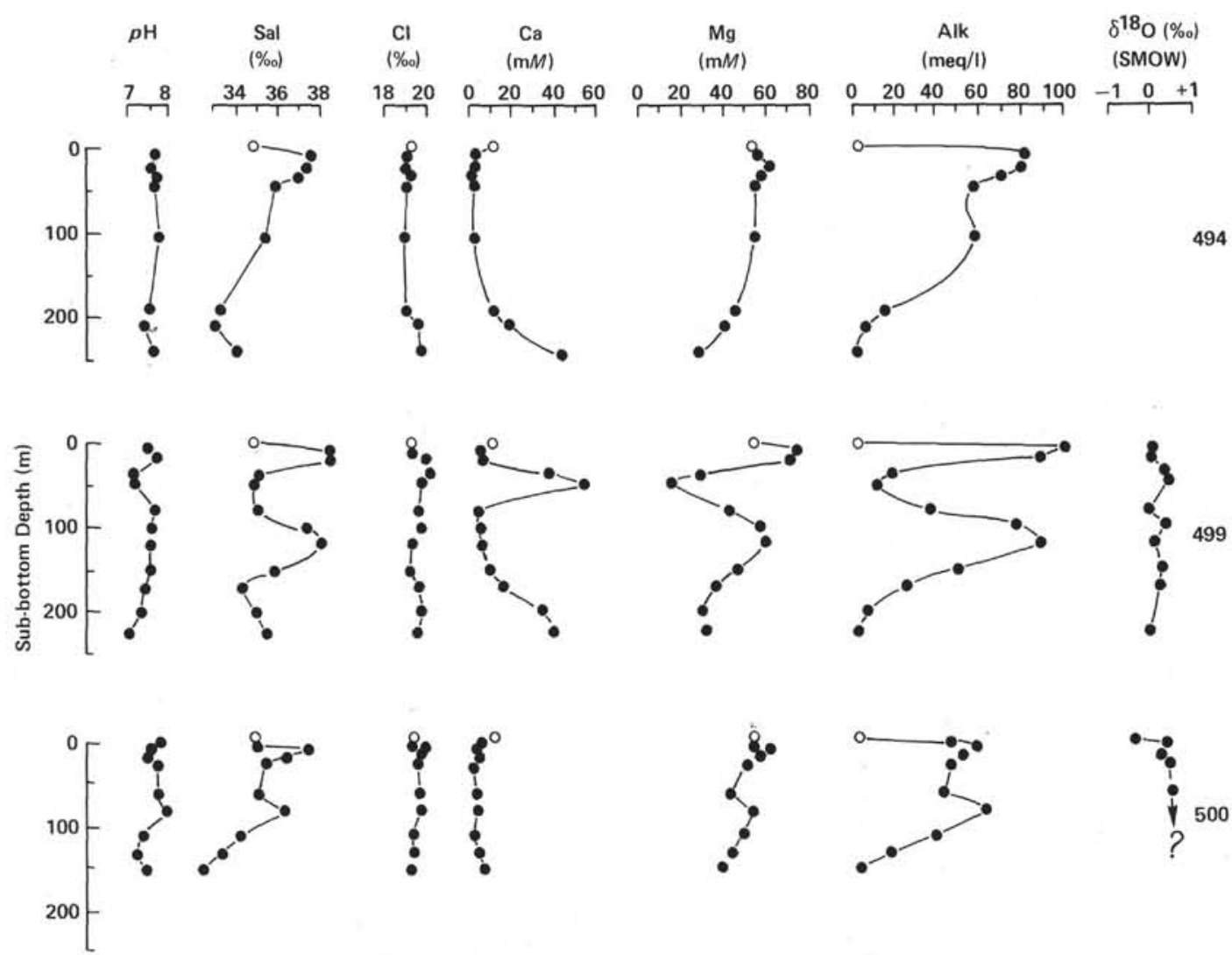

Figure 4. Interstitial water chemistry, Sites 499, 500 (Middle America Trench floor), and Site 494 (lower Trench slope, without hydrates). (All concentrations are in $\mathrm{mM}$, except where otherwise indicated; $\mathrm{O}=$ bottom water.)

mineralogy of the $<2-\mu \mathrm{m}$ fraction is dominated by smectite with minor admixtures or traces of illite and kaolinite present.

Organic carbon (Fig. 2) in the hemipelagic sediments of Unit 1 reaches maximum values of $2.4 \%$, but, on average, stays below $1 \%$, with a downhole decrease corresponding to the downward decrease in sedimentation rates from $37 \mathrm{~m} / \mathrm{m}$.y. in the Quaternary to $7 \mathrm{~m} / \mathrm{m}$.y. in the late Miocene. The brown abyssal clay of Unit 2, with very low sedimentation rates, is practically free of organic matter (Fig. 2).

\section{Interstitial Water Chemistry (Fig. 3)}

Concentration profiles for the various major ionic constituents show only small changes from the average seawater composition. The upper 100 meters of the sediments is characterized by a slight minimum in dissolved sulfate, a maximum in alkalinity and ammonia, as well as a minimum in magnesium. This can be understood in terms of increased sulfate reduction rates in these upper sediments, which are characterized by higher contents of organic carbon (Fig. 2). In these upper sediments, also, a production of calcium and a consumption of magnesium occurs. A slight maximum in dissolved strontium between 250 and 300 meters indicates calcium carbonate recrystallization.

\section{Sites 499 and 500: Deep-Sea Trench}

\section{Sedimentary Facies}

Trench Holes 499, 499A, and 499B, and 500, 500A, and 500B (drilled at water depths of $6127,6132,6127$, 6123,6127 , and $6127 \mathrm{~m}$, respectively) penetrated a sedimentary succession of alternating trench-fill turbidites and hemipelagic muds underlain by pelagic sediments and ocean crust basalt. The turbidites include nannofossil muds, laminated sandy muds, muddy sands, and sands up to coarse sands. They are rich in volcanogenic components and derived from the volcanic chain in Guatemala. The vertical stratigraphic succession of the pelagic sediments encountered in any single hole is incomplete in terms of thickness or facies types compared to that at Site 495 , but all pelagic facies types listed for Site 495 were encountered individually in the holes drilled in the Trench. Reduction in thickness or omission of individual facies members appears to be due to faulting.

Mineralogy of the silt fraction (20-63 $\mu \mathrm{m}$, see Heinemann and Füchtbauer, this volume) of the trench-fill sediments (fine-grained divisions of turbidites, hemipelagic sediments) reveals a predominance of volcanic glass or feldspar for the material with a density $>2.43$ $\mathrm{g} / \mathrm{cm}^{3}$ in most samples. Noteworthy is the occurrence of a small proportion (usually less than 10 or $5 \%$ ) of 
quartz. The $<2.43-\mathrm{g} / \mathrm{cm}^{3}$ density fraction is dominated by volcanic glass. Zeolites (clinoptilolite and heulandite) and opal come next (in descending order of abundance). In the clay fraction $(<2 \mu \mathrm{m})$ montmorillonite is the prevalent mineral. It is accompanied by some illite and small amounts or traces of kaolinite.

Organic carbon in Site 499 (Fig. 2) ranges between 3.6 and $0.4 \%$, decreasing generally downward. Strong fluctuations correlate with variations in grain-size between materials that are sandy (low $\mathrm{C}_{\text {org }}$ ) and those that are clay-rich (high $\mathrm{C}_{\mathrm{org}}$ ).

\section{Interstitial Water Chemistry (Fig. 4)}

Concentration depth profiles for these sites are characterized by extreme variations in alkalinity, calcium, and magnesium, particularly for Site 499 . Similar variability can be observed in the distribution of salinity. These phenomena will be discussed later, but it is evident that important diagenetic processes characterize these sediments.

\section{DISCUSSION}

\section{Diagenesis of Organic Carbon}

In all the holes drilled during Leg 67 , with the exception of Hole 495, diagenesis of organic matter has led to depletion of dissolved sulfate in the uppermost 10 to 20 meters of the sediment column. This sulfate depletion is implied from the large increases in alkalinity. Below the sulfate reduction zone, carbon dioxide reduction and fermentation processes lead to methane generation (Claypool and Kaplan, 1974). Associated with these processes are very sharp increases in alkalinity, with alkalinity values in Hole 496 exceeding $120 \mathrm{meq} / \mathrm{l}$. In addition, large increases in dissolved ammonia and phosphate occur. Also, especially because of the large increases in bicarbonate (alkalinity) concentration, a maximum value in salinity is observed. The large increases in ammonia are important, because this constituent can undergo ion exchange reactions with the solid phases, particularly clay minerals. These ion exchange reactions lead to the observed increases in dissolved magnesium and perhaps potassium observed at Sites 494, 496, 499, and 500. Similar observations have been made in the Timor Trough (Cook, 1974), in the Japan Trench (Moore and Gieskes, 1980), and in the Gulf of California (Gieskes et al., in press).

At all sites, values of alkalinity, ammonia, phosphate, and magnesium decrease with increases in depth after having reached maximum values in the upper sediment column. These decreases are associated with removal reactions into the solid phases by precipitation (phosphates, carbonates), ion exchange or fixation into clay minerals (ammonia, magnesium), or alteration of reactive materials, such as volcanic ash (possible sink for magnesium). In Site 479 sediments (Guaymas Basin, Gulf of California) downward decreases in magnesium have been associated with the generation of distinct layers of dolomite (Gieskes et al., in press). No such reactions have been observed in the sediments recovered during Leg 67 , but especially the reversals in the cal- cium, magnesium, and alkalinity profiles in the turbidites of Site 499 could be explained in this manner. Decreases in magnesium in the deeper parts of Sites 494, 498 , and 499 are accompanied by increases in calcium. At Site 500 and the slope Sites 496 and 497, no such increases in dissolved calcium are observed, and, indeed, calcium concentrations remain below seawater concentrations as a result of carbonate precipitation. The increases in dissolved calcium with depth at Sites 494, 498, and 499 could be due to alteration reactions involving basalts or volcanic materials in deeper, unsampled sections of the sediment column, but this interpretation must remain necessarily speculative.

\section{Reactions in Pelagic Sediments-Site 495}

In Hole 495 only small changes in concentration occur, especially in calcium and magnesium. In the upper 100 meters, because of the higher organic carbon contents (Fig. 2), sulfate reduction and ammonia generation are more important than in the deeper section. Typically such a situation can lead to a minimum in dissolved sulfate, indicating that no steady-state profile in dissolved sulfate has been reached (Gieskes, 1975). Values of dissolved strontium show a maximum in the carbonate zone, presumably as a result of carbonate recrystallization processes. This maximum coincides with the transition from pelagic carbonate oozes to chalks. The sharp decrease in dissolved silica in Core 39 occurs at the same level as do the first cherts.

\section{Sites 496 and 497-the Gas Hydrate Problem}

Below the sulfate reduction zones of Sites 494, 496, $497,498,499$, and 500, methane generation becomes the dominant process involving the decomposition of organic matter, as has been shown in a previous section. Dissolved methane concentrations (not measured), particularly in Holes 496 and 497, with their high organic carbon contents in the upper 200 meters of the sediment column, may become appreciable, and could rise to concentrations above $50 \mathrm{mM}$, thus allowing the formation of gas hydrates (Claypool and Kaplan, 1974; Hand et al., 1974; Miller, 1974; Milton, 1976). These clathrates can be stable to considerable depths (Claypool and Kaplan, 1974; Trofimuk et al., 1974), but depending on pressure and temperature gradients, the gas hydrates will decompose again at depths 100 to 1100 meters below the sediment/water interface. Generally, it is believed that the gas-hydrate layers above this lower stability limit can act as cap rocks for a reservoir of released gas (Dillon et al., 1980). Indeed the base of the hydrate zone is often characterized by the so-called "bottomsimulating reflector" on seismic profiles, the reflector being associated with the occurrence of free gas (Tucholke et al., 1977). Hydrate zones are characterized by poor seismic reflections (e.g., Shipley et al., 1979) and anomalously high seismic velocities (Stoll et al., 1971).

The gas hydrates will start to form where methane concentrations have reached sufficiently high levels to enter the hydrate stability field. Upon hydrate formation, water molecules will be withdrawn from the solution to form hydrates with an average formula $\mathrm{CH}_{4}$. 
$6 \mathrm{H}_{2} \mathrm{O}$ (Claypool and Kaplan, 1974). If the processes leading to the production of carbon dioxide and methane do not involve a large production of water, then, of course, a net removal of water would occur, which, in turn, would lead to increased chloride concentrations. At none of the sites with high alkalinities and methane concentrations (with or without hydrates) have significant increases in chloride been observed, with the possible exception of Site 499 ( $<4 \%$ change). On the contrary, at Site 496 and 497, large decreases in chloride are common. The latter phenomenon is highly significant, particularly because the chloride decrease is associated with an increase in the $\mathrm{H}_{2}{ }^{18} \mathrm{O}$ content of the recovered interstitial waters. This is not expected if the fresh water causing the dilution of the salts were derived from meteoric waters advected from continental sources through aquifers in the deeper-lying strata.

In the next few paragraphs we wish to analyze these observations in the light of the following hypothesis:

The dilution of the pore waters with heavy water is caused by the dissolution of gas hydrates in the retrieved cores. The progressive increase of $\mathrm{H}_{2}{ }^{18} \mathrm{O}$ with depth in this "artifact" (i.e., the progressive decrease in observed chlorinities) would be the result of increased hydrate concentrations as well as decreased porosities with depth.

Trofimuk et al. (1974) suggest that water trapped in gas hydrates, in analog with ice, is enriched in $\mathrm{H}_{2}{ }^{18} \mathrm{O}$ when compared with water in which the gas hydrates formed. O'Neil (1968) reports a value of 1.003 for the fractionation factor between water and ice. Hydrates, like ice, do not incorporate salt ions in the crystal structure (Hand et al., 1974). If the chloride gradient is indeed due to dilution by fresh water released from the gas hydrates, one estimates for a dilution of a factor of two a change of $\delta^{18} \mathrm{O}$ of about 2.0 to $2.5 \%$ (Fig. 5), yielding a fractionation factor of at least 1.004 , assuming the undiluted pore waters to have a $\delta^{18} \mathrm{O}=0 \%$. This factor is slightly above the value of 1.003 reported by O'Neil (1968) for the oxygen isotope fractionation factor of the ice-water system.

For our hypothesis to be true, one must assume that waters enriched in chloride and depleted in $\mathrm{H}_{2}{ }^{18} \mathrm{O}$ as a result of the original formation of gas hydrates either have migrated out of the system or have diminished the concentration gradients in chloride and $\mathrm{H}_{2}{ }^{18} \mathrm{O}$ by diffusive processes. Though there is no doubt that upward advection of water does occur in rapidly deposited sediments as a result of compaction and perhaps gas-hydrate formation, this expelled water will not exit from the sedimentary column (Einsele, 1977) unless sedimentation breaks occur. Thus a chloride enrichment and a depletion in $\mathrm{H}_{2}{ }^{18} \mathrm{O}$ should have been observed in the upper parts of the sediment column, unless this enrichment or depletion has been completely obliterated by diffusive exchange with the overlying ocean or lost in the sedimentary hiatuses reported for Hole 496 (Site 496 report, this volume). Considering the substantial decreases in chloride observed, this must have implied equally substantial transport of chloride out of the system. At accumulation rates of 130 to $200 \mathrm{~m} / \mathrm{m}$.y. during the Quaternary, one calculates a scale length for diffusion (diffusion coefficient $6 \times 10^{-6} \mathrm{~cm}^{2} / \mathrm{s}$ ) of 90 to 140 meters in these sediments; thus enrichments in chloride caused below this depth should still be noticeable. Unfortunately no in situ samples for pore waters were obtained at these sites that would have served to check on the latter hypothesis. Of course, any migration of chloride away from the zone of gas-hydrate formation would automatically result in a chlorinity reduction if all the clathrate were to decompose upon retrieval of the cores. Thus the hydrate hypothesis at present explains the isotope data and downward chlorinity decrease best, though it is rather surprising that no chloride increase has been observed in the upper sections. The expected
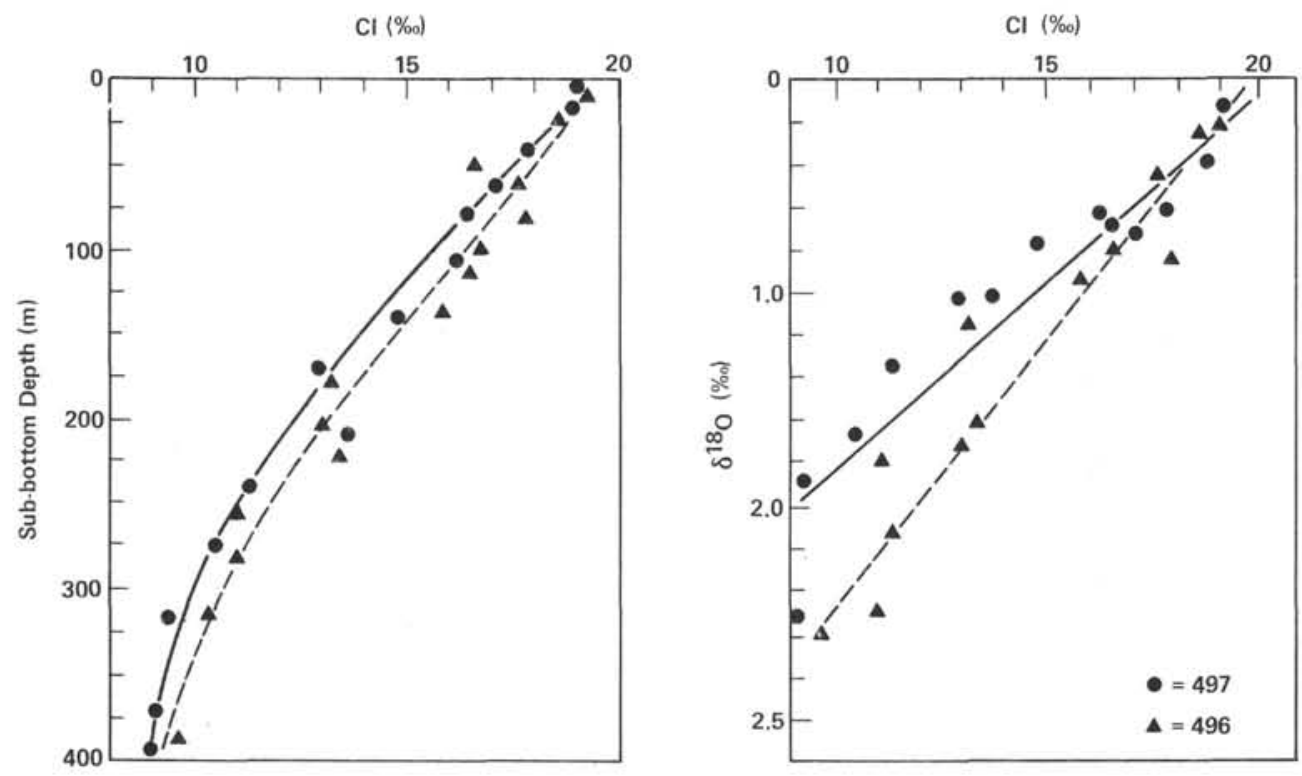

Figure 5. Chlorinity in Holes 496 and 497 and $\mathrm{Cl}-\delta^{18} \mathrm{O}$ correlation. 
chloride increase should occur above the roof of the hydrate zone, which in Holes 496 and 497 may be close to the sediment surface, if methane concentrations exceeding the solubility of $\mathrm{CH}_{4}$ in the pore water are linked to the bottom of the sulfate reduction zone. This is in line with the observation on seismic profile GUA-13 (Fig. 1) of weak seismic reflectors characteristic of hydrate zones extending upwards to the immediate vicinity of the seafloor. In this case the expected chloride maximum and $\delta^{18} \mathrm{O}$ minimum indeed could have been lost by diffusive processes.

An additional requirement for the hypothesis to be true is that in view of the rather gradual decreases in chloride and increases in $\delta^{18} \mathrm{O}$ there must be a very gradual increase of gas hydrates with depth; and because of the randomness of sample selection, these hydrates must occur throughout the sediments and cannot be restricted to specific lithologies such as ash layers. Yet on Leg 67, hydrates were recovered on board only from coarsergrained sediments (i.e., ash layers). The possibility that hydrates must occur throughout the sediments has to be given serious consideration, however, particularly in view of the vigorous degassing of the fine-grained sediments on board and the poor seismic reflections throughout the hydrate zone (Fig. 1).

In general we conclude that the observed depletion in chloride and enrichment in $\delta^{18} \mathrm{O}$ may indeed be the result of hydrate decomposition, though the lack of chloride enrichment and heavy isotope depletion in the upper section of the sediment column and the requirement for the pervasive presence of gas hydrates and their gradual increase in concentration with depth leave open some questions to be tackled during future drilling in hydrate zones.

A result of the hydrate decomposition hypothesis, of course, would be that observed decreases with depth in alkalinity, magnesium, potassium, and other components would be less in situ than suggested by the observations in Table 1 and Figure 3. Again, future investigations using the in situ pore-water sampler will be helpful in unravelling this problem.

An alternative to the above hydrate decomposition hypothesis would be the existence of a low chlorinity pool of water in a region of hydrate decomposition below 400 meters sub-bottom depth. This reservoir of relatively fresh water, enriched in $\mathrm{H}_{2}{ }^{18} \mathrm{O}$, would communicate with the overlying sediments mainly by diffusive exchange, contributing to the observed gradients in chloride and in $\delta^{18} \mathrm{O}$. The question immediately arises as to what volumes of water have to be accumulated to contribute substantially to the observed chloride decrease. If one considers a 400-meter-thick column of sediment with an average porosity of $60 \%$, this column contains about 24 liters of water (1300 moles). If at the base of this column the chlorinity is half that of seawater, the implication is that the entire column is diluted by about 25 to $30 \%$ (cf., Fig. 5); hence about 55 moles of $\mathrm{CH}_{4} \cdot 6$ $\mathrm{H}_{2} \mathrm{O}$ are needed to yield the dilution water by decomposition. This would therefore require that $1.8 \%$ of carbon in the original sediment be converted into methane, which would explain the downhole decrease in organic matter content. To produce the calculated volume of $\mathrm{H}_{2}{ }^{18} \mathrm{O}$-enriched water, at least 400 meters of this sediment should have passed the lower stability boundary of hydrate. These calculations do require a rather largescale production of methane, regardless of whether the chlorinity and oxygen isotope gradients are due entirely to hydrate decomposition in the samples or due to diffusive transport in the pore-water column within the hydrate zone.

In conclusion, the sediments of Holes 496 and 497 do show some very interesting features with respect to gashydrate formation processes. A major feature is the effect of these processes on the chlorinity and oxygen isotopic composition of the interstitial waters. Whether these observations are due solely to the decomposition of hydrates in the samples or to advection and diffusion from an underlying reservoir of waters relatively enriched in $\mathrm{H}_{2}{ }^{18} \mathrm{O}$, the data clearly indicate that gas-hydrate formation causes substantial fractionation of ${ }^{18} \mathrm{O}$ isotopes, which should leave a noticeable effect on the interstitial waters.

It seems imperative to study the oxygen isotopic composition of interstitial waters in conjunction with geochemical studies of interstitial waters at sites that show decreasing chlorinities with depth. Often such chloride decreases have been ascribed to intrusions of fresh waters of continental origin (Barnes et al., 1979; Moore and Gieskes, 1980), but seldom have oxygen isotope studies confirmed such conclusions.

\section{ACKNOWLEDGMENTS}

The first author's participation in Deep Sea Drilling Project Leg 67 was sponsored by the National Science Foundation and the second author's by the Deutsche Forschungsgemeinschaft. Additional costs were borne by a National Science and Engineering Research Council of Canada grant to R. Hesse and by NSF grant OCE 7724102 to J. Gieskes. C. Fong did the isotopic analyses at the Laboratoire de Géochimie Isotopique, Université de Québec a Montréal; K. Thompson performed the shipboard chemical analyses on board Glomar Challenger; and $\mathrm{K}$. Weber did additional shore-based analyses at Oklahoma Geological Survey. R. Mclver, H. Füchtbauer, R. McDuff, D. Milton, and M. Kastner offered helpful advice and critical comments, in part on an early draft of this paper. L. Erskine did the typing; R. Yates drafted the figures. The authors are grateful for this support.

\section{REFERENCES}

Barnes, R. O., Gieskes, J. M., Horvath, J., and Akiyama, W., 1979. Interstitial water studies, Legs 47A, B. In Ryan, W. B. F., Sibuet, J.-C., et al., Init. Repts. DSDP, 47, Pt. 2: Washington (U.S. Govt. Printing Office), 577-581.

Claypool, G. E., and Kaplan, I. R., 1974. The origin and distribution of methane in marine sediments. In Kaplan, I. R. (Ed.), Natural Gases in Marine Sediments: Mar. Sci. 3:99-140.

Clayton, R. N., Friedman, I., Graf, D. L., Mayeda, T. K., Meents, W. F., and Shimp, N. F., 1966. The origin of saline formation waters: 1. Isotopic composition. J. Geophys. Res., 71(16):3869-3882.

Cook, P. J., 1974. Geochemistry and diagenesis of interstitial fluids and associated calcareous oozes, DSDP Leg 27, Site 262, Timor Trough. In Veevers, J. J., Heirtzler, J. R., et al., Init. Repts. DSDP, 27: Washington (U.S. Govt. Printing Office), 463-480.

Dillon, W. P., Grow, J. A., and Paull, C. K., 1980. Unconventional gas hydrate seals may trap gas off Southwest U.S. Oil Gas J., 78(1):124-130

Einsele, G., 1977. Range, velocity, and material flux of compaction flow in growing sedimentary sequences. Sedimentology, 24: 639-655.

Epstein, S., and Mayeda, T., 1953. Variations of $\mathrm{O}^{18}$ content of water from natural sources. Geochim. Cosmochim. Acta, 4:213-224. 
Gieskes, J. M., 1974. Interstitial water studies, Leg 25. In Simpson, E. S. W., Schlich, R., et al., Init. Repts. DSDP, 25: Washington (U.S. Govt. Printing Office), 361-394.

1975. Chemistry of interstitial waters of marine sediments. Annu. Rev. Earth Planet. Sci., 3:433-453.

Gieskes, J. M., Elderfield, H., Lawrence, J. R., Johnson, J., Meyers, B., and Campbell, A., in press. Geochemistry of interstitial waters and sediments, Leg 64, Gulf of California. In Curray, J. R., Moore, D. G., et al., Init. Repts. DSDP, 64: Washington (U.S. Govt. Printing Office).

Gieskes, J. M., and Lawrence, J. R., 1976. Interstitial water studies, Leg 35. In Hollister, C. D., Craddock, C. et al., Init. Repts. DSDP, 35: Washington (U.S. Govt. Printing Office), 407-424.

Gieskes, J. M., Lawrence, J. R., and Galleisky, G., 1976. Interstitial water studies, Leg 38. In Talwani, M., Udintsev, G., et al., Init. Repts. DSDP, 38: Washington (U.S. Govt. Printing Office), 121-133.

Hand, J. H., Katz, D. L., and Verma, V. K., 1974. Review of gas hydrates with implication for ocean sediments. In Kaplan, I. R. (Ed.), Natural Gases in Marine Sediments: Mar. Sci., 3:179-194.

Hesse, R., Foreman, H. P., Forristall, G. Z., Heezen, B. C., Hekel, H., Hoskins, R. H., Jones, E. J. W., Kaneps, A. G., Krashenninikov, V. A., MacGregor, I., and Okada, H., 1974. Walther's facies rule in pelagic realm $\rightarrow$ a large-scale example from the Mesozoic-Cenozoic Pacific. Z. Dtsch. Geol. Ges., 125(1):151-172.

Ibrahim, A. K., Latham, G. V., and Ladd, J., 1979. Seismic refraction and reflection measurements in the Middle America Trench, offshore Guatemala. J. Geophys. Res., 84:5643-5649.

Lawrence, J. R., and Gieskes, J. M., 1981. Constraints on water transport and alteration in the oceanic crust from the isotopic composition of pore water. J. Geophys. Res, 86:7924-7934.

Manheim, F. T., and Sayles, F. L., 1974. Composition and origin of interstitial waters of marine sediments, based on deep sea drill cores. In Goldberg, E. D. (Ed.), The Sea: Mar. Chem., 5:527-568.
Miller, S. L., 1974. The nature and occurrence of clathrate hydrates. In Kaplan, I. R. (Ed.), Natural Gases in Marine Sediments: Mar. Sci., 3:151-177.

Milton, D. S., 1976. Methane hydrate in the sea floor-a significant resource? In Meyer, R. F. (Ed.), The Future Supply of Naturemade Petroleum and Gas, Technical Reports, Ist Unitar Conference on Energy and the Future: New York (Pergamon Press), pp. 927-943.

Moore, G. W., and Gieskes, J. M., 1980. Interaction between sediment and interstitial water near the Japan Trench, Leg 57. In Scientific Party, Init. Repts. DSDP, 56, 57, Pt. 2: Washington (U.S. Govt. Printing Office), 1269-1275.

O'Neil, J. R., 1968. Hydrogen and oxygen isotope fractionation between ice and water. J. Phys. Chem., 72:3683-3684.

Shipley, T. H., Houston, M. H., Buffler, R. T., Shaub, F. J., McMillenik, J., Ladd, J. W., and Worzel, J. L., 1979. Seismic evidence for widespread possible gas hydrate horizons on continental slopes and rises. Am. Assoc. Pet. Geol., Bull., 63:2204-2213.

Stoll, R. D., Ewing, J., and Bryan, G. B., 1971. Anomalous wave velocities in sediments containing gas hydrates. J. Geophys. Res., 76:2090-2094.

Trofimuk, A. A., Cherskiy, N. V., and Tsarev, V. P., 1974: Mechanisms for fractionation of isotopes of water and gas in crustal zones of hydrate formation. Dokl. Akad. Nauk SSSR, 215: 1226-1229.

Tucholke, B., Bryan, G. M., and Ewing, J. I., 1977. Gas-hydrate horizons detected in seismic-profiler data from the western North Atlantic. Am. Assoc. Pet. Geol. Bull., 61(5):698-707.

von Huene, R., Aubouin, J., Azéma, J., Blackinton, G., Carter, J. A., Coulbourn, W. T., Cowan, D. S., Curiale, J. A., Dengo, C. A., Faas, R. W., Harrison, W., Hesse, R., Hussong, D. M., Ladd, J. W., Muzylöv, N., Shiki, T., Thompson, P. R., and Westberg, J., 1980. Leg 67: The Deep Sea Drilling Project Mid-America Trench transect off Guatemala. Geol. Soc. Am. Bull., Pt. 1, 91:421-432. 


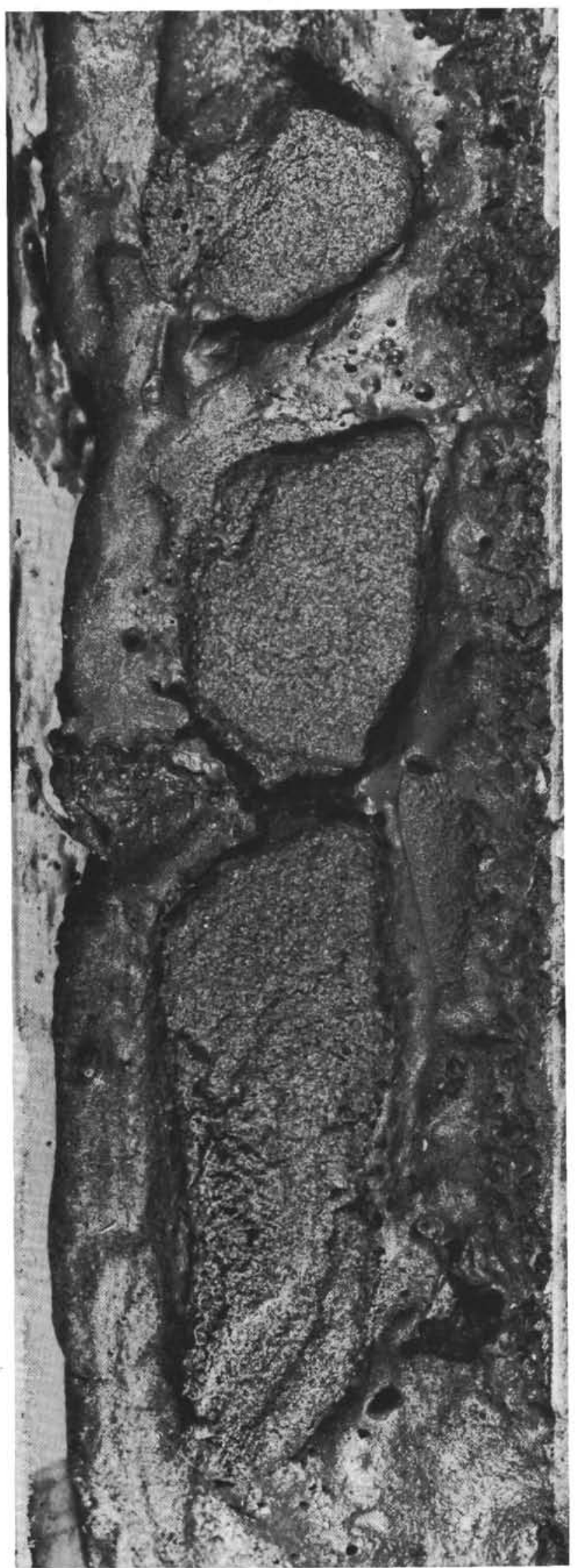

Plate 1. Thawing of "frozen" volcanic ash-DSDP Sample 498A$15-2,110-125 \mathrm{~cm}$-during core inspection aboard ship. 